\title{
Mihi whakatau
}

Moana Nepia

E rau rangatira mā, Ngāti Whatua, Ngāti Paoa, ngā manuhiri tūārangi, e Gernot... e mihi kau atu ana rā ki a koutou. Talofa lava, kia orana, Willkommen ... welcome!

To the many chiefs gathered here, including those from Ngāti Whatua and Ngāti Paoa, distinguished visitors from afar, Gernot Böhme.... greetings and welcome to you all.

I've chosen today to share some poetry with you that gathers ideas regarding atmospheres evoked through Māori ritual greetings and lament, and to touch on some of the themes that this symposium is addressing. ${ }^{1}$

When we talk about atmosphere in Māori, one of the words we use is rangi. Rangi is also day, weather, sky, and Sky Father, one of our ancestors. Rangi also translates as air and melody. When we are talking about atmospheres, we are talking about ourselves, not something that is separate from us.

There are many atmospheres in Māori thinking, many states and names for Rangi. Rangi, our father, is also an ancestor from whom perception arises in whakapapa or genealogies. Our connection to atmospheres both outside and inside, the nature of perception and existence are all understood in terms of whakapapa, a relational way of understanding the world.

The first poem I'd like to share with you, Tangi, is by New Zealand Māori poet Hone Tuwhare, who was from Te Tai Tokerau, the Northern region of Aotearoa/NZ. He wrote in English and was a master at evoking senses of atmosphere and place.

Tangi is a lament, a crying and weeping. One of the first things we do in a formal Māori address is to draw together our many ancestors, those who have passed away. Sharing this way, we also come closer together.

Tangi

I did not meet her

on the bordered path

nor detect her fragrance

in the frolic of violets and carnations.

She did not stroll riverward

to sun-splash and shadows

to willows trailing garlands

of green pathos

Death was not hiding in the cold rags

of a broken dirge

Nor could I find her

in the cruel laughter of children

the curdled whimper of a dog

But I heard her with the wind

crooning in the hung wires 


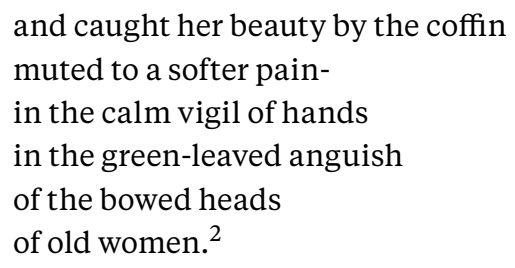

The second poetic reference I want to make is to Rangiuia, who was a nineteenth-century tohunga (scholar) from Ngāti Porou at the Rawheoro whare wānanga (school of learning) at Uawa (Tolaga Bay), a part of the country that my ancestors come from, and that I call home. In a waiata tangi (lament) he wrote for his son, ${ }^{3}$ he refers to a particular state of Rangi in cloud formations from the south. People who know the history, or who are from the Ngāti Porou region, may know how this state of Rangi was also used to refer to a portent of doom.

In the last poem I will share with you, titled Grief, I refer to the separation of Rangi or Ranginui (Sky Father) and Papatūānuku (Earth Mother) as a space and source of continual lament, perceived in the movement of rain, water and cloud. This is a short extract:

Grief carries us home,

ebbs and flows with the tide,

paddles and surges through veins,

powers and floats, surging through water.

Grief takes charge, inspiring command,

declaring another call, to arms, to action, to move

again, to haul and lift up over rocky shore.

Rise and fall of this melody is rangi,

hugging, hovering, soaring, yearning over land.

Grief trembles, expanding air,

thunders and tumbles clouded.

Grief howls wind over sand,

galloping in from the sea,

swoops up to smother views

from the edge of an abyss.

Above and below, towards and away,

resoundings shudder

to land torn, numb,

dripping to sodden dust.

Tangi a lament moves and cries. ${ }^{4}$

In ritual acknowledgements of those who have passed, we are not just lamenting, we are coming together as the living faces of our ancestors. We are the embodiment of atmosphere. 


\section{Endnotes}

1. This is an edited version of the mihi whatakatau (opening address) for the 2014 Interstices Under Construction Symposium, 22 November, 2013, at the Design Theatre, NICAI, The University of Auckland. Thanks to Moata McNamara for editorial support.

2. Tuwhare, H. (1994). Deep River Talk: Collected poems. Honolulu, HI: University of Hawaiłi Press, p. 22.

3. Ngata, A. (1958). The origin of Māori carving. Te Ao Hou. Vol. 22, p. 35

4. Nepia, M. (2012). Te Kore-Exploring the Māori concept of void. PhD Thesis. AUT University, Auckland. Vol. 1, pp. 9-10. http://aut. researchgateway.ac.nz/handle/10292/5480/NepiaM_vol1 